\title{
An Empirical Study Of Market Orientation In The Life Insurance Industry In South Africa
}

Yvonne Kabeya Saini, University of Witwatersrand, South Africa Kenosi N. Mokolobate, University of Witwatersrand, South Africa

\begin{abstract}
This paper examines the implementation of market orientation in the South African life insurance firms. A non probability sampling method was employed to select 102 respondents from life insurance organisations. Factor analysis method was used to analyse the data. Results of this study indicate that assessing market orientation practices using customer focus, competitor focus and inter-functional coordination variables is applicable to the South African life insurance industry. The findings suggest that the market orientation scale appears to capture well the construct of market orientation in the South African cultural context and confirms that market orientation is a worthwhile management goal to adopt. The findings are consistent with the literature. The results suggest that the use of sales people in measuring market orientation should be generalised with caution as this factor scored the lowest in the factor loading for customer focus. The Narver \& Slatter (1990) scale was found to be reliable in measuring market orientation in the South African life insurance industry.
\end{abstract}

Keywords: life insurance; South Africa; market orientation

\section{INTRODUCTION}

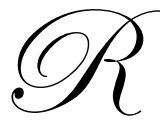

esearch on marketing orientation concept has received increased interest in the last few decades. Marketing orientation has received this much focus of time and effort by academicians as this has been driven by the gaps in the strategic role of marketing as a discipline in the success of firms. The implementation of the marketing concept of market orientation is one of the major research streams in strategic marketing to be developed during the last two decades (Guo 2002; Sin et al. 2003). Studies suggest that a market orientation approach on the part of a firm could be "regarded as an indication of its implementation of the 'modern marketing' concept (Anwar 2008:191). Market orientation is the implementation of the marketing concept and so a market-orientated organisation is one whose actions are consistent with the marketing concept (Narver \& Slater, 1990). The marketing concept is the cornerstone of the marketing discipline (Kohlika \& Jaworski, 1990) and so market orientation has been widely acknowledged as important and it has been deduced that market orientation is the very heart of modern management and strategy (Narver \& Slater, 1990). Since the market orientation scale was first developed in a Western culture, its applicability to other cultures has been questioned though other studies (Sin et al (2003) have shown that the Nervier \& Slater's (1990) scale can be generalised across cultures. These observations are in agreement with the results of the studies conducted in low income countries (LICs) (Orelowitz 1995; Cowling 1998; Nwokah \& Maclayton 2006; Burgess \& Nyajeka 2007; Nwokah 2008). Despite the growing body of evidence in support of market orientation, its applicability in life insurance industry in South Africa has not been established. This paper sought to explore the extent to which marketing orientation is practiced and implemented in the life insurance industry in South Africa. Marketing orientation research has mainly been done in developed countries and in specific industries, notably the manufacturing. The study endeavoured to fill the gap in understanding the implementation and practice of marketing orientation in the South African life insurance industry. The objective of the study was to collect data in a South African Life Insurance industry to determine the extent of market orientation and see if the Narver \& Slater (1990) scale was found to be reliable and valid. 


\section{BACKGROUND}

Insurance is a type of service for risk management used to hedge against the risk of a possible loss. Life insurance deals with how people ensure that they remain with means to provide for themselves when they are past employment age. It includes products like life retirement funds which hold assets for benefits at resignation, retirement, dismissal or retrenchment. It is important in studying market orientation in that life insurance products are bought and not consumed immediately but has a long time span before consumption and so the risks for life insurance products are higher than for fast moving consumer goods for example. Life insurance services are high in credence attributes than search goods which can be evaluated before purchase. Due to the nature of the service offered, it is of great value to explore how market orientation is regarded and implemented in this industry.

South Africa has a well developed insurance industry and it provides substantial investment capital for the country. The overall average insurance penetration for emerging markets is $3.9 \%$ whereas for South Africa the figure is $14 \%$. The insurance sector in general provides significant employment opportunities. Finance, Insurance and real estate contributes to over 20\% of the GDP in South Africa in comparison to manufacturing's contribution of $17 \%$, wholesale, retail and accommodation $15 \%$ and transport, storage and communication of $10.7 \%$. In 2007 , the life insurance industry in South Africa generated approximately R255 billion in revenue from R163.6 billion in 2005 employed close to about 90,000 people. In June 2010, the total assets for the long term insurance industry were R1.14 trillion (Association for Savings and Investment Africa, 2011)

There are over 20 life insurance companies in South Africa. The major ones are Sage Life Ltd, Sanlam Life Insurance Ltd, Liberty Group, Old Mutual, Discovery Life, and Outsurance. The insurance sector in South Africa has traditionally operated subject to strict regulation and strong protection from international competition. But due to the globalisation process that has occurred over the past few decades, the competition in the life insurance industry has become intense. This competition has provoked major restructuring of the insurance companies. The long-term survival of a Life Insurance firms in such an increasingly competitive environment depends on its ability to satisfy customers' demands efficiently and effectively and hence the importance of understanding the implementation of market orientation.

\section{Theoretical Frameworks}

There has been limited in-depth empirical research into how far marketing principles and practices are applied in the financial services industry (Lado, Maydeu-Olivares et al. 1998). Baker (1993) has strongly criticised the insurance industry for a failure to adopt the marketing concept. He cites a case study of the implementation of a change programme in AIB by Bourke (1992) as an example that proved that marketing techniques were transferable into the financial sector as well. But Baker (1993) suggested that this is the exception rather than the rule and concluded that generally there is much evidence over a long period that the banking profession had largely failed in the development of a genuine marketing orientation. In South Africa, Cowling's (1998) and Orelowitz's (1995) study confirmed Baker's (1993) assertions. They demonstrated that market orientation in the South African insurance industry was less prevalent in the companies they studied. Baker (1993) noted that bank marketing was more a myth than reality, consisting of the trappings rather than the substance of marketing. Often market orientation was incorrectly interchanged with advertising; restricting this concept to only being a function of the marketing department. Market orientation is a term used when referring to the implementation of the marketing concept (McCarthy and Perreault 1984; Agarwal, Erramilli et al. 2003). Consequently, a market-orientated organisation is one whose actions are consistent with the marketing concept.

Market orientation consists of three conceptually closely related and equally important behavioural constituents; customer orientation, competitor and inter-functional coordination (Naver \& Slater, 1990; De Luca et al, 2010; Sin et al., (2003)) and the constructs have been found to be the robust measure of market orientation (Conduit J and Mavondo, 2001). In other words, market orientation reflects the extent to which a firm internalises the marketing concept as a primary organising principle of the firm (De Luca et al, 2010). Market orientation is a term used when referring to the implementation of the marketing concept (McCarthy \& Perreault 1984; Agarwal et al., 2003). Consequently, a market-orientated organisation is the one whose actions are consistent with the marketing concept. It defines the set of activities where a variety of departments within an organisation would participate in 
generating market intelligence, such as a growing competition, disseminating it, and taking actions in response to it (Maydeu-Olivares and Lado 2003). Several studies have identified that market orientation is a strong source of a sustainable competitive advantage (Slater and Narver 1994; Pelham and Wilson 1996; Pelham 2000)

Further, market orientation has been linked to product innovation performance and that is it positively linked to the firm's ability to innovate (De Luca et al, 2010). The benefits of market orientation is theoretically supported as it provides an unifying focus and clear vision to an organisation's strategy centred around creating superior value for customer (Kohli \& Jaworski, 1990). Marketing concept is the management philosophy that recognises that the customer should be the focal point of all activity in the organisation (Leyland and Pitt 2001). According to Walker (2001), until the mid-1950s, the traditional view of marketing held that the key to profitability was greater sales volume. Therefore it was marketing responsibility to sell whatever the factory could produce (Webster 1998). The short-term tactical sales approach was replaced by a long term strategic orientation (Webster 1998) that encouraged businesses to look at customer needs rather than at transient products (McGee and Spiro 1988). This was referred to as "market orientation" and hence a market-orientated organisation aims at creating value for customers (Osuagwa 2006)..

\section{Marketing Concept}

Marketing concept is a management philosophy that recognises that the customer should be the focal point of all activity in the organisation (Leyland and Pitt 2001). The literature reveals diverse definitions of the marketing concept. Felton (1959) defined the marketing concept as a corporate state of mind that insists on the integration and coordination of all the marketing functions, for the basic purpose of producing maximum long-range corporate profits. Houston (1986) defined the concept as a willingness to recognise and understand customers' needs and wants and the willingness to adjust any of the marketing mix elements to satisfy these needs and wants. In contrast, the marketing concept was viewed broadly and defined as the construct as a philosophy of business management (Lavidge 1966; Bell \& Emory 1971; Konopa and Calabro 1971; Levitt 1976; Stampfl 1978). They recognised that marketing concept was based on "...a company-wide acceptance of the need for customer orientation, profit orientation and recognition of the important role of marketing in communicating the needs of the market to all corporate departments" (Kohli \& Jaworski 1990). Marketing concept forms a cornerstone of the marketing discipline. It is essentially a business ideal or a policy statement (Barksdale and Darden 1971; McNamara 1972).

\section{Market Orientation: The Construct}

Previous studies have considered market orientation as the central ingredient of a successful organisation's culture (Kohli and Jaworski 1990; Slater and Narver 1995). Most of the relevant studies that have been carried out on market orientation have been based on different perspectives developed by Kotler and Clarke (1987), Shapiro (1988), Narver and Slater (1990), Kohli and Jaworski (1990), and Deshpande et al (1993) among others.

Market orientation is a tendency "to determine the needs and wants of target markets and satisfy them through the design, communication, pricing, and delivery of appropriate and competitive viable products and services" (Kotler and Clarke 1987:31).

Rivera (1995) described market orientation as a strategy used to reach a sustainable competitive advantage (SCA). Competitive advantage resulted from the use of resources and capabilities to generate differential satisfaction in profitable market. Sustainability was achieved because the performance of the market orientation's behaviours required complex organisational knowledge that could not easily be duplicated by competitors. Sin et al (2003) noted that Narver and Slater's (1990) study, hypothesised that market orientation was a one-dimensional construct consisting of three components, having equal importance, namely; customer, competitor and interfunctional coordination focus.

Firstly, customer orientation; the collection of data regarding the market and market potential. Customer orientation includes the active encouragement of customer comments, complaints, and after-sale service emphasis. It also includes regular evaluation of ways to create superior products /value and the regular measurement of customer 
satisfaction. Customer orientation is the sufficient understanding of one's target buyers to be able to create superior value for them continuously (Narver \& Slater 1990).

Secondly, competitor orientation entails the regular monitoring of competitor activity or in other words deals with generating competitive intelligence, periodic review of competitor's patenting activity. It is made up of the collection and use of market information on competitors to develop marketing plans and using the sales force to monitor and report competitor activity. Competitor orientation means that a seller understands the short-term strengths and weaknesses as well as long-term capabilities and strategies of both current and potential competitors of their business (Day \& Wensley 1988). Therefore, customer orientation and competitor orientation include all of the activities involved in acquiring information about the buyers and competitors in the target market and disseminating it throughout the business (Narver \& Slater 1990).

Thirdly, inter-functional coordination. This deals with communicating between scientists and business development and sharing project goals and responsibilities Inter-functional coordination relates to how well marketing information is shared between departments (Narver \& Slater 1990). It requires the involvement of all departments in the preparation of business plans and strategies and the integration of the activities between departments. It also needs the interaction of marketing personnel with other departments and regular interdepartmental meetings to discuss market trends, development and customer needs.

Pelham and Wilson (1996) asserted that a market-orientated organisational culture may work as a critical driver of various aspects of superior performance including product quality, new product success, and profitability not only for large firms (Kohli \& Jaworski 1990; Narver \& Slater 1990; Deshpande et al., 1993; Jaworski \& Kohli 1993; Slater \& Narver 1994; Morgan \& Strong 1998; Hult \& Ketchen 2001; Noble, Sinha et al. 2002) but also small and medium enterprises (Pelham and Wilson 1996; Appiah-Adu and Singh 1998; Pelham 1999; Pelham 2000).

Hult \& Ketchen (2001) study found more factors in measuring market orientation, namely, customer orientation, competitor orientation, inter-functional coordination, entrepreneurship, innovativeness and organisational learning. In Hult \& Ketchen's (2001) study all factors were found to be significant at the 0.05 significance level. The latter three factors were derived from the innovativeness scale, (Hurley and Hult 1998), organisational learning scale Hurley \& Hult 1998) and entrepreneurship scale (Naman \& Slevin 1993). Liu's (1995) study on market orientation results indicated that large and extra-large firms were more market orientated than medium size firms, and hardly any difference existed between large and extra-large firms.

Therefore, a model that provides a better fit of the data is a model comprising of three correlated scores underlying all measurements, based on the original MKTOR scale (Narver and Slater 1990) of customer orientation, competitor orientation and inter-functional coordination. For the purposes of understanding the practice and implementation of marketing orientation in South Africa, the study used the three constructs of market orientation, customer, competitor and interfunctional orientation.

\section{METHODOLOGY}

The study used the constructs as developed by Narver \& Slater (1990) and adapted the questionnaire from Nwokah (2008). The questionnaire had 20 questions. The questionnaire was administered to middle and senior managers in the Life Insurance companies operating in South Africa. Different individuals from the Life Insurance companies were targeted. The respondents were broken in this category, 35 from senior marketing directors, middle manager, marketing managers, sales manager and financial managers respectively.

Section A of the questionnaire contained demographic details. Section B consists of 20 MKTOR scale items used to measure customer orientation, competitor orientation, and inter-functional coordination. Respondents were asked to rate the 20 questions on a 7-point scale. Specifically, the respondents were asked to indicate the extent to which their business does engage in the practice of market orientation or does not, i.e. the scale ranges from "very high extent" (7), to "no extent at all" (1). The number of scale points has been increased to 7 as this helps with the scale reliability (Churchill 1999). These statements measured manager's opinion of the degree to which his or her organisation was market orientated. A copy of the questionnaire can be found in Appendix A. 


\section{Pilot Study}

A pilot study was conducted on a group of MBA students and 5 marketing practitioners in order to establish whether the instrument could be used in a South African context. Based on the pilot study no adjustments needed to be made on the questionnaire before final administration. This reinforced the questionnaire's validity and also addressed possible ambiguities in the questions.

\section{Procedure For Data Collection}

A list of the South African Life Insurance companies was obtained from the Life Offices Association of South Africa (LOA). These candidates were approached telephonically and requested to participate in the study, Questionnaires with completion instructions were either hand delivered, where possible, or faxed to respondents to overcome geographical dispersion. Receipt of the questionnaire was confirmed telephonically and deadlines were agreed with the respondents. This was followed up with an email indicating appreciation for their participation.

\section{Data Analysis And Interpretation}

The responses from the first part of the questionnaire were factor analysed using the principal components method. NCSS (Number Cruncher Statistical System) statistical software was chosen to perform the analysis. Raw data was captured in the NCSS spreadsheet and later transformed to obtain the sum of the values of market orientation.

\section{RESULTS}

\section{Demographic Profile Of Respondents}

A total of 113 completed questionnaires were collected, representing a response rate of $71 \%$. Only 11 of the completed questionnaires were found to be invalid as they had either missing or extreme values and were thus discarded. In total, 102 questionnaires were used in the analysis representing a 64.5\% response rate. In this study the sample consisted of a slightly higher percentage of females than was previously anticipated, the percentage being $59 \%$. Males on the other hand made up the remaining $41 \%$ percent of the respondents in the sample. The largest age category, from the sample, fell in the 35 to 49 age group. This was followed by the respondents in the 25 to 34 age group category making $32 \%$ of the respondents. Females occupied $60 \%$ of senior marketing positions compared to only $40 \%$ of males.

\section{Factor Analysis Results}

Table 1: Principle Component Analysis: Un-Rotated Solution

\begin{tabular}{|l|l|l|l|}
\hline & $\begin{array}{l}\text { Factor 1: } \\
\text { Customer Orientation }\end{array}$ & $\begin{array}{l}\text { Factor 2: } \\
\text { Competitor Orientation }\end{array}$ & $\begin{array}{l}\text { Factor 3: } \\
\text { Inter-functional } \\
\text { Coordination }\end{array}$ \\
\hline Eigen value & 9.64 & 2.32 & 1.49 \\
\hline \% Variance explained & 48.22 & 11.63 & 7.45 \\
\hline $\begin{array}{l}\text { \% Cumulative variance } \\
\text { explained }\end{array}$ & 48.22 & 59.85 & 67.30 \\
\hline
\end{tabular}

Looking at the results in Table 1, the 3 factors, customer orientation, competitor and inter-functional coordination orientations explained $48.22 \%, 11.63 \%$ and $7.45 \%$ respectively, together representing $67.30 \%$ of the item variance. In order to understand the underlying structure Varimax with rotation was used in the analysis. The overall Cronbach's $\alpha$ for the scale was 0.935813 , which was greater than the value of 0.7 suggested by Nunnally (1978). Customer orientation had the highest overall mean 'rating score' suggesting that as a factor or basic dimension of market orientation, it may be relatively more important than the others, at least according to the respondents in this study. 


\section{Construct Validity Analysis}

To determine construct validity, the market orientation scale was tested for both convergent and discriminant validity. "Convergent validity refers to the degree of agreement between two or more measures of the same construct" (Tse, Sin et al. 2003:569). Evidence of convergent validity of the market orientation scale was examined through simple correlations among the three components of the scale. The results reported in the study show that correlations among the three components of market orientation ranged from 0.881 to 0.970 , and all correlations were significant at $p<0.01$.

Table 2: Correlations Among Three Components Of Market Orientation

\begin{tabular}{|l|l|l|l|}
\hline & $\begin{array}{l}\text { Customer } \\
\text { Orientation }\end{array}$ & $\begin{array}{l}\text { Competitor } \\
\text { Orientation }\end{array}$ & $\begin{array}{l}\text { Inter-functional } \\
\text { Coordination }\end{array}$ \\
\hline Customer orientation & 1.00 & 1.00 & \\
\hline Competitor orientation & $0.881^{* *}$ & $0.959^{* *}$ & 1.00 \\
\hline Inter-functional coordination & $0.970^{* *}$ & & \\
\hline
\end{tabular}

**Statistically significant at $\mathrm{p}<0.01$ level

Each of the components was highly correlated ( 0.881 and above) with each other. The correlation between customer orientation-competitor orientation was found to be $(0.881, \mathrm{p}<0.01)$ and significant at $\mathrm{p}<0.05$.The correlation of customer orientation-inter-functional coordination was found to be $(0.970, \mathrm{p}<0.01)$ and significant at $\mathrm{p}<0.01$. As for the correlation of competitor orientation-inter-functional coordination was found to be $(0.959, \mathrm{p}<$ 0.01 ) and significant at $\mathrm{p}<0.01$.Therefore, the pattern of correlations indicated that three components were convergent on a common construct, thereby providing evidence of convergent validity. These results were comparable to the results achieved by Narver and Slater (1990). "Discriminant validity concerns the degree to which measures of conceptually distinct constructs differ" (Tse et al. , 2003).

\section{Rotated Factor Analysis Solution}

In order to choose the number of factors to retain from the analysis the cumulative percentage and the scree test results in the eigenvalues after Varimax Rotation section were analysed. It was observed that $18.61 \%$ of the data were captured in the first factor, $25.99 \%$ in the second and $22.81 \%$ in the third factor. This can also be evidenced in the scree test as well as the cumulative percentage that $67.81 \%$ of the data is contained in the first three eigenvalues, see Table 3, below.

Table 3: Principle Component Analysis: Rotated Solution

\begin{tabular}{|l|l|l|l|}
\hline & $\begin{array}{l}\text { Factor 1: } \\
\text { Customer Orientation }\end{array}$ & $\begin{array}{l}\text { Factor 2: } \\
\text { Competitor Orientation }\end{array}$ & $\begin{array}{l}\text { Factor 3: } \\
\text { Inter-functional } \\
\text { Coordination }\end{array}$ \\
\hline Eigen value & 3.721 & 5.198 & 4.64 \\
\hline $\begin{array}{l}\text { \% Curiance explained } \\
\text { explained }\end{array}$ & 18.61 & 25.99 & 23.21 \\
\hline
\end{tabular}

\section{Customer Orientations}

In the analysis, when analysing the solution, only variables with factor loadings of 0.40 and above were considered significant in interpreting the factors. The Cronbach $\alpha$ for customer orientation was 0.871 . Examining the factor loadings and absolute factor loadings after Varimax rotation section, of the principle component analysis, it can be seen that statement 7 is the weakest on Factor 1, customer orientation with factor loading < 0.5. (See Table 4 and Appendix 2). With the exception of statement 7, statement one to eight had the highest loadings $(>0.60)$ on the first factor which accounted for $18.61 \%$ of the variance on all factors. The finding that loaded onto this factor are the 
same as that of Narver \& Slater (1990) and Cowling (1998) and Nwokah (2008). The factors together under the heading Customer Orientation were reliable with the Cronbach $\alpha$ of 0.871 surpassing the 0.7 threshold recommended by Nunnally (1978) for the test of scale reliability.

\section{Competitor Orientation}

The Cronbach $\alpha$ for competitor orientation was 0.929 . Examining the factor loadings and absolute factor loadings after Varimax rotation section, of the principle component analysis, it can be seen that statement 9 is the weakest on the second factor. Statement 10 to 14 had the highest loadings $(>0.70)$ on the second factor which accounted for $25.99 \%$ of the variance. The statements that loaded onto this factor are the same as the Narver \& Slater's (1990), Cowling's (1998) and Nwokah's (2008) statements grouped together under the heading Competitor Orientation and were reliable with the Cronbach $\alpha$ of 0.929 greater than 0.7 .

Table 4: Market Orientation: Factor Analysis Detailed Results

\begin{tabular}{|l|l|}
\hline Factor & Factor Loading \\
\hline Customer Focus & $\mathbf{0 . 7 2 3}$ \\
\hline 1.We encourage customers' comments and complaints because they help us do a better job & $\mathbf{- 0 . 7 8 3}$ \\
\hline 2.We have a strong commitment to our customers & $\mathbf{- 0 . 8 2 8}$ \\
\hline 3.We are always looking at ways to create customer value in our product & $\mathbf{- 0 . 8 3 3}$ \\
\hline 4.We measure customer satisfaction on a regular basis & $\mathbf{- 0 . 8 0 5}$ \\
\hline 5.After sales strategy is an important part of our business strategy & $\mathbf{- 0 . 7 8 8}$ \\
\hline 6.We define quality as an extent to which our customers are satisfied with our products & $\mathbf{- 0 . 6 4 2}$ \\
\hline 8.Customer satisfaction is assessed at least once every three months & \\
\hline Competitor Focus & $\mathbf{- 0 . 7 0 9}$ \\
\hline 9.We regularly monitor our competitors' marketing efforts & $\mathbf{0 . 8 0 6}$ \\
\hline 10.We regularly collect marketing data on our competitors to help direct our marketing plans & $\mathbf{- 0 . 7 8 5}$ \\
\hline 11.Our sales people are instructed to monitor and report on competitor activities & $\mathbf{- 0 . 8 2 4}$ \\
\hline 12.We respond rapidly to competitors' actions & $\mathbf{- 0 . 8 1 1}$ \\
\hline 13.Our top managers often discuss competitors' actions & $\mathbf{- 0 . 7 5 4}$ \\
\hline 14.We consider opportunities based on competitive advantage & \\
\hline Inter-Functional Coordination & $\mathbf{- 0 . 5 4 0}$ \\
\hline 15.In our firm the marketing people have a strong input into developing new products /services & $\mathbf{- 0 . 7 7 6}$ \\
\hline 16.Marketing information is shared with all departments & $\mathbf{- 0 . 7 4 1}$ \\
\hline 17.All departments are involved in preparing business plans /strategies & $\mathbf{- 0 . 7 9 1}$ \\
\hline 18.We do good jobs integrating the activities of all departments & $\mathbf{- 0 . 8 1 7}$ \\
\hline 19.The marketing people regularly interact with other departments on a formal basis & $\mathbf{- 0 . 5 8 8}$ \\
\hline 20.Marketing is seen as a guiding light for the entire firm & \\
\hline
\end{tabular}

\section{Inter-Functional Coordination}

Cronbach $\alpha$ for Factor 3, for Inter-functional coordination is 0.905. Examining the factor loadings and absolute factor loadings after Varimax rotation section, of the principle component analysis, it can be seen that statements 15 to 20 had the highest loadings ( $>0.50$ ) on the third factor which accounted for $23.21 \%$ of the variance. The statements that loaded onto this factor are the same as the Narver \& Slater's (1990) statements, Cowling's (1998) and Nwokah's (2008) statements that group together under the heading inter-functional coordination and were found to be reliable with the Cronbach $\alpha$ of 0.905 greater than 0.7 . Therefore, it could be concluded that the three factors were associated with the hypothesised three factor model first proposed by Narver and Slater (1990)

The results of this study indicated that there were three factors of market orientation practices in the context of South African life insurance companies. They were market orientation, competitor orientation and interfunctional coordination. These factors explained a percentage total variance of $67.81 \%$. (See Appendix 1, $3 \& 4$ ). The results were based on the factor loadings of the items on the individual factors. A higher degree of ordering under each factor was shown by all items with factor loadings greater than 0.50. Cronbach's $\alpha$ yields the best lower 
bound to the reliability of these constructs. Items in the factorial groups were found to be reliable and valid according to Cronbach $\alpha$, with the whole scale value of 0.936 . They were also shown to fit a three-factor model consisting of market orientation, competitor orientation and inter-functional coordination.

In this study the South African Life Insurance industry seems to be an exception as they have adopted market orientation principles. It seems that Life Insurance companies acknowledge the importance of implementing market orientation within their organisations. Market-orientated Life Insurance organisations have similar characteristics to those identified in market-orientated food and beverage organisations in Nigeria (Nwokah 2008) and retail outlets in Zimbabwe (Burgess \& Nyajeka 2007).

One statement with a low factor loading of less than 0.50 was "Our firm would be a lot better off if the sales force worked a bit harder". A possible reason for the low factor loading is that most sales forces were perceived to work hard in their respective firms as they were paid commission based on the amount of business they brought in. Overall, the results strongly supported the construct validity of the Narver \& Slater's (1990) scale in the Life Insurance industry in South Africa. The study brought out an interesting result in that the contribution of the sales force is not important in the South Africa life insurance industry. The construct 7 was stated as follows; "our firm would be a lot better off if the sales force worked a bit harder". The factor loading for this was 0.181 suggesting that whether the sales force worked harder or not, their contribution to being customer focus is negligible. Equally, the construct 20 which read "the marketing people regularly interact with other departments on a formal basis, was one of the lower scores with the factor loading of 0.588 . On the other hand, the construct on item 15 which was stated as follows; "In our firm the marketing people have a strong input into developing new products /services had a score of 0.54 , this was the lowest. Construct 15 and 20 have implication on the role marketing plays in this industry. (See appendix 2).

\section{Discussion}

The results indicate that three components converged on a common construct. The results of the principle component analysis of the factor analysis support the Narver and Slater (1990) findings of the three component model of marketing orientation, i.e. consists of customer orientation, competitor orientation and inter-functional coordination. These factors explain a percentage total of $67.3 \%$. Although the market orientation scale was originally developed in the US at the strategic business unit (SBU) level of a manufacturing firm, the findings in this study appears to suggest that the scale captures well the construct of market orientation in the South African Life Insurance industry.

The resulting factors from this study, in conjunction with the above discussion, leads to an acceptance of Market orientation factors are customer orientation, competitor orientation and inter-functional coordination as derived from Narver \& Slater's (1990), Orelowitz's (1995) and Cowling's (1998) studies.

Only those factors that are found in the Narver and Slater (1990) were found to be reliable, valid and could be used across a variety of boundaries, companies, industries and cultures as has been found in this study. Therefore, the findings suggest that the market orientation of Life Insurance companies in South Africa is high relative to other studies (Moerdyk 2001). They seem to be an exception as they have adopted market orientation principles.

This study has examined the extent of market orientation in the South African Life Insurance industry. The role of marketing both as a specialist function and dominant organisational culture in the Life Insurance industry in South Africa has grown, as life insurers have become more concentrated and face intensive competition.

Our findings suggest that Narver and Slater's scale is a reliable and valid scale that can be used in the South African insurance industry. Although the scale was originally developed in the US at the strategic business unit (SBU) level, our findings suggest that the scale appears to capture well the construct of market orientation in a South African cultural context. The results confirm that market orientation is a worthwhile management goal to adopt.

The findings suggest that Life Insurance companies in South Africa implement market orientation. It seems that Life Insurance companies acknowledge the importance of implementing market orientation within their 
organisations. Findings are also consistent with the literature that is based on the Narver and Slater's (1990) definition of market orientation. They also support the notion that market orientation is an important determinant of a firm's performance. Therefore, South African Life insurance managers have to consider their underlying business philosophy and become more customer and competitor oriented at the corporate level, in branches as well as across the different functional departments.

From a managerial perspective, this study invalidates the long held belief that market orientation, in South African Life Insurance companies, is not prevalent. Life Insurance companies all over the world are under growing pressures from governments, investors, lobbies, and general public to be efficient and to remain competitive to help them achieve these objectives, the results of the present study suggests that managers in such organisations should adopt market orientation, a kind of philosophy that seeks to identify potential problems while they can still be managed and then to solve them in the time before they become too big, or ideally before they even occur or take place.

Furthermore, Life Insurance companies wishing to satisfy their customers better and outperform their competitors need to constantly monitor their behaviour and internal processes. Narver and Slater's(1990) market orientation scale could be used as a diagnostic tool to identify areas where specific improvements are needed, and to pinpoint aspects of a firm's market orientation that require work. In addition, periodic measurement of a firm's market orientation can help South African Life Insurance managers track changes over time. The three components of the market orientation can be used to develop appropriate training programs that can improve the staff's understanding of the activities involved in developing market orientation. Functional managers can also use the market orientation framework to set policies that develop and consider market orientation as a necessary and essential business process. One issue to be explored further and considered is the role of sales people as its loading was very low.

Other South African non-insurance companies may benefit from this research as it empirically addresses the issue of whether all businesses should focus on market orientation or not. This is important as devoting resources to develop a market orientation is considered useful as it does lead to higher performance in the business environment. Management should also work in collaboration with other workers in the company and share information about customers and competitors with these workers. Ideally as part of having a market orientation, cross-functional teams can investigate problems that occur across the organisation not just in single departments, and can suggest possible improvements in response to changing customer needs. The instrument used in the research is available as a checklist for management to measure their company's market orientation. Given that the current study draws data from South African Life Insurance industry, the findings of this study cannot be generalised for all business environments. Future research will attempt to extend this to other business sectors of the South African economy.

\section{CONCLUSION}

The results suggest that measuring market orientation using customer, competitor and inter-functional focus is applicable. The factor loading fitted the market orientation model except for one construct in the customer focus. The importance of including the sales force in being customer focus had the lowest factor loading and so it use is not conclusive. Other studies did not have the same results and concluded that the model for measuring market orientation fitted well. It is there therefore important to explore why the sales force construct contributed minimal to the customer focus of market orientation in the South African life insurance industry. This is calls for further studies as life insurance companies' utilities large numbers of sales force to promote and sell its varied products. The results should therefore carefully be generalised. 


\section{ABOUT THE AUTHORS}

Yvonne Kabeya Saini ${ }^{1}$ (BA, University of Zambia, MBA, University of Illinois) Yvonne is a Lecturer and a PhD student at Wits Business School at the University of Witwatersrand, in Johannesburg, South Africa.

Kenosi Norman Mokolobate, BSc Mechanical Engineering (University of Cape Town, Cape Town, South Africa, MBA, Wits Business School, University of Witwatersrand, Johannesburg, South Africa. He is currently employed at Liberty Life Holdings, an insurance company in Johannesburg, South Africa.

\section{REFERENCES}

1. Agarwal, S., Erramilli, K. and Dev, C. (2003) Market orientation and performance in service firms: Role of innovation, Journal of Services Marketing, 17(1), pp. 68-82.

2. Anwar, S. A. (2008) A factor analytic investigation of the construct of market orientation, International Journal of Management, 25(1), pp. 186-197.

3. Appiah-Adu, K. and Singh, S. (1998) Customer orientation and performance: a study of SMEs, Management Decision, 36(6), pp. 385-394.

4. $\quad$ Association for Savings and Investment South Africa (2011). http://www.asisa.co.za/downloads/media\%20releases/2010/september/20100902_Media\%20Release_Life $\% 20$ industry $\% 20$ reports $\% 20 \mathrm{a} \% 20$ steady $\% 20$ decline $\% 20$ in $\% 20$ surrender $\% 20$ and $\% 20$ lapse $\% 20$ rates.pdf

5. Baker, M. J. (1993) Bank marketing - myth or reality, International Journal of Bank Marketing, 11(6), pp. 5-11.

6. Barksdale, H. C. and Darden, B. (1971) Marketers' Attitude Toward the Marketing Concept, Journal of Marketing, 35(October), pp. 29-36.

7. Bell, M. L. and Emory, C. W. (1971) The faltering marketing concept, Business Horizons, 22(June), pp. 76-83.

8. Bourke, K. J. (1992) Implementing a marketing action programme for AIB group, Long Range Planning,

9. Burgess, S. M. and Nyajeka, P. (2007) Market orientation and performance in low-income countries: The case of Zimbabwean retailers, Advances in International Management, 20, pp. 215-257.

10. Churchill, G. A. (1999) Marketing Research-Methodological Foundations, 7th ed., The Dryden Press, Philadelphia.

11. Conduit J \& Mavondo T F (2001), Journal of Business Research (51), pp 11-24.

12. Cowling, H. G. (1998) The relationship between market orientation and business performance. Unpublished Research Report submitted in partial fulfilment of the requirements for the MBA degree, University of Witwatersrand, Johannesburg.

13. Day, G. S. and Wensley, R. (1988) Assessing advantage: A framework for diagnosing competitive superiority, Journal of Marketing, 52, pp. 1-20.

14. De Luca M L, Verona G \& Vicari S (2010) Journal of Product Innovation management 27, pp299-320.

15. Deshpande, R., Farley, J. U. and Webster, E. F. (1993) Corporate culture, customer orientation and innovativeness in Japanese Firms: A Quadrad analysis, Journal of Marketing 57(January), pp. 23-27.

16. Felton, A. P. (1959) Making the marketing concept work, Harvard Business review, 37(July-August), pp. 55-65.

17. Guo, C. (2002) Market orientation and business performance: a framework for service organisations, European Journal of Marketing, 36(9/10), pp. 1154-1163.

18. Houston, F. S. (1986) The marketing concept: what it is and what it is not, The Journal of Marketing, pp. 81-87.

19. Hult, G. T. M. and Ketchen, D. J. (2001) Does market orientation matter?: A test of the relationship between positional advantage and performance, Strategic Management Journal, 22, pp. 899-906.

20. Hurley, R. F. and Hult, G. T. M. (1998) Innovation, market orientation, and organizational learning: an integration and empirical examination., Journal of Marketing, 62(July), pp. 42-54.

21. Jaworski, B. J. and Kohli, A. K. (1993) Market orientation: antecedents and consequences, The Journal of Marketing, pp. 53-70.

\footnotetext{
${ }^{1}$ Corresponding author: Yvonne.saini@wits.ac.za or +27 117173586 or P O Box 98, Wits, 2050, Johannesburg, South Africa
} 
22. Kohli, A. K. and Jaworski, B. J. (1990) Market orientation: the construct, research propositions, and managerial implications, The Journal of Marketing, pp. 1-18.

23. Konopa, L. J. and Calabro, P. J. (1971) Adoption of the market concept by large Northeastern Ohio manufacturers, Akron Business and Economic Review, 2(Spring), pp. 9-13.

24. Kotler, P. and Clarke, R. N. (1987) Marketing for health care organisations, Prentice-Hall, Englewood Cliffs, NJ.

25. Lado, N., Maydeu-Olivares, A. and Rivera, J. (1998) Measuring market orientation in several populations, European Journal of Marketing, 32(1/2), pp. 23-39.

26. Lavidge, R. J. (1966) Marketing Concept often gets only lip service, Advertising Age, October, p. 52.

27. Levitt, T. (1976) The marketing mode, New York: McGraw-Hill Book company.

28. Leyland, F. and Pitt, D. N. (2001) South African Marketing Cases for Decision Makers, 3rd ed., Juta and Company.

29. Liu, H. (1995) Market orientation and firm size: an empirical examination in UK firms, European Journal of Marketing, 29(1), pp. 57-71.

30. Maydeu-Olivares, A. and Lado, N. (2003) Market orientation and economic performance in the European insurance industry: A mediational model, International Journal of Service Industry Management, 14(284309).

31. McCarthy, E. J. and Perreault, J. W. D. (1984) Basic Marketing, Homewood, IL: Richard D. Irwin, Inc.

32. McNamara, C. P. (1972) The present status of the marketing concept, The Journal of Marketing, pp. 50-57.

33. Moerdyk, C. (2001) Looking your customers in the eyes., Marketing Mix, 19(4), pp. 42-44.

34. Morgan, R. E. and Strong, C. A. (1998) Market orientation and dimensions of strategic orientation, European Journal of Marketing, 32(11/12), pp. 1051-1073.

35. Naman, J. L. and Slevin, D. P. (1993) Entrepreneurship and the concept of fit: a model and empirical tests. , Strategic Management Journal 14(2), pp. 137-154.

36. Narver, J. C. and Slater, S. R. (1990) The effect of a market orientation on business profitability, Journal of Marketing, 54(4), pp. 20-35.

37. Noble, C. H., Sinha, R. K. and Kumar, A. (2002) Market orientation and alternative strategic orientations: a longitudinal assessment of performance implications, The Journal of Marketing, pp. 25-39.

38. Nunnally, J. C. (1978) Psychometric Theory, 2 ed., McGraw-Hill, New York, NY.

39. Nwokah, N. G. (2008) Strategic market orientation and business performance, European Journal of Marketing, 42(3/4), pp. 279-286.

40. Nwokah, N. G. and Maclayton, D. W. (2006) Customer-focus and business performance: the study of food and beverages organizations in Nigeria, Measuring Business Excellence, 10(4), pp. 65-76.

41. Orelowitz, A. (1995) Assessing the Relationship between a market orientation and Business Performance. Unpublished Research Report submitted in partial fulfilment of the requirements for the MBA degree. University of Witwatersrand, Johannesburg.

42. Osuagwa, L. (2006) Market orientation in Nigerian companies, Journal of Marketing Intelligence and Planning, 24(6), pp. 608-631.

43. Pelham, A. M. (1999) Influence of environment, strategy, and market orientation on performance in small manufacturing firms, Journal of Business Research, 45(1), pp. 33-46.

44. Pelham, A. M. (2000) Market orientation and other potential influences on performance in small and medium-sized manufacturing firms, Journal of Small Business Management, 38(1), pp. 48-67.

45. Pelham, A. M. and Wilson, D. T. (1996) A longitudinal study of the impact of market structure, firm structure, strategy, and market orientation culture on dimensions of small-firm performance, Journal of the Academy of Marketing Science, 24(1), pp. 27-43.

46. Rivera, J. (1995) L'Orientation Marché: une strategie concurrentielle performante. Université Catholique de Louvain, Belgium.

47. Shapiro, B. P. (1988) What the hell is Market Oriented? , Harvard Business Review, 66(NovemberDecember), pp. 119-125.

48. Sin, L. J. M., Tse, A. C. B., Yau, O. H. M., Chow, R. and Lee, J. S. Y. (2003) Market orientation and business performance: a comparative study of firms in Mainland China and Hong Kong European Journal of Marketing, 37(5/6), pp. 230-232.

49. Slater, S. F. and Narver, J. C. (1994) Does competitive environment moderate the market orientationperformance relationship?, The Journal of Marketing, pp. 46-55. 
50. Stampfl, R. W. (1978) Structural constraints, consumerism, and the marketing concept, MSU Business Topics, 26(3), pp. 5-16.

51. Tse, A. C. B., Sin, L. Y. M., Yau, O. H. M., Jenny, S. Y. L. and Chow, R. (2003) Market orientation and business performance in a Chinese business environment, Journal of Business Research, 56, pp. 227-239.

52. Walker, H. J. L. (2001) The measurement of market orientation and its impact on business performance, Journal of Quality Management, 6, pp. 139-172.

53. Webster, E. F., Jr (1998) Rediscovering the marketing concept, Business Horizons, 31(May-June), pp. 2939. 